\title{
'Morden Sunrise' Rose
}

\section{Campbell G. Davidson \\ Morden Research Station, Agriculture and Agri-Food Canada, Unit 100-101 Route 100, Morden, MB, R6M 1 Y5 Canada}

Additional index words. hardiness, disease resistance, Parkland, ornamentals, Rosa

'Morden Sunrise' rose (Rosa L.) is a new, disease-resistant, semi-double, yellow-flowered introduction of the Parkland cultivargroup from the AAFC-Morden Research Station rose breeding program. 'Morden Sunrise' will survive to zone 3 with only minor injury (Ouellet and Sherk, 1967; Sherk and Buckley, 1968). Repeated crossing with the more traditional shrub and garden roses has resulted in recombinants with good floral qualities and greatly improved hardiness. Hardiness in this rose cultivar group was obtained originally from $R$. arkansana Porter, a species native to the Great Plains region of North America (Collicutt, 1992; Marshall, 1977). 'Morden Sunrise' combines hardiness, abundant flowering, disease resistance and excellent plant form in a hardy shrub-type Parkland rose. This is the $12^{\text {th }}$ introduction from the AAFC-Morden Research Center in the "Parkland" group, and the first with yellow flowers.

\section{Origin}

'Morden Sunrise' has a complex pedigree (Fig. 1). The pollen parent in the final cross was 'Sunsprite' (syn. 'Fresia'), a Kordes rose released in 1977 with deep yellow flowers (28 petals) (Cairns, 1993). Other key parents included 'Assiniboine', 'Hazeldean', Rosa arkansana, and 'White Bouquet'. 'White Bouquet', a 1956 white-flowered Floribunda rose released by Boerner, contributed floral qualities. 'Hazeldean', a hybrid R. pimpinellifolia L. (syn. R. spinossisima L.) released in 1948 , contributed both hardiness and yellow flower coloration (Cairns, 1993). Rosa arkansana Porter, a native prairie-hardy tetraploid rose, and 'Assiniboine', the first Parkland rose, have been very influential in developing roses well adapted to the harsh prairie growing conditions (Davidson, 1999a, 1999b). The name 'Morden Sunrise' was selected to reflect the yellow-orange color of an early morning sunrise.

\section{Description}

Plants are relatively open, have erect upright canes, and range from 62 to $83 \mathrm{~cm}$ (mean $70 \mathrm{~cm}$ ) in height and 65 to $75 \mathrm{~cm}$ (mean $70 \mathrm{~cm}$ ) in width. Current season bark is green-grey

Received for publication 16 Jan. 2001. Accepted for publication 4 June 2001. I thank L.M. Collicutt and the late H.H. Marshall for their involvement in the development of the 'Parkland' Rose series, as well as the technical support of L. Dyck and numerous summer students. Without their help, progress would have been impossible.
[144B, Royal Horticultural Society (RHS), 1986], which changes gradually to greenbrown (RHS 146B) on mature stems. In late fall to early winter the bark color continues to change (brown-red, RHS 183B). Mature stems have a small to moderate number of prickles, 5.4 to $9.2 \mathrm{~mm}$ in length (mean $7.6 \mathrm{~mm}$ ). Also, smaller prickles are present on current season stems, but are infrequent.

The compound leaves (odd pinnate) have three to seven leaflets per leaf, with five leaflets predominating. The terminal leaflet ranges from 4.6 to $5.6 \mathrm{~cm}$ in length (mean $5.0 \mathrm{~cm}$ ) and 2.7 to $3.8 \mathrm{~cm}$ (mean $3.2 \mathrm{~cm}$ ) in width. Leaflet margins are serrate, while shape is oval tapering to a broad point; color is dark, shiny green (RHS 147A) on the upper surface and glabrous, duller, green (RHS 148B) below. Petioles are green (138B), glandular with sparse prickles or hairs, and canaliculate (grooved). Petiolules are small (2.0 to $2.2 \mathrm{~mm}$ ) and green in color.

Inflorescences contain 2 to 15 flowers (mean 8.0). Semi-double flowers are 6 to 8 $\mathrm{cm}$ in diameter (mean $7 \mathrm{~cm}$ ) and appear slightly concave when fully open $(\approx 2.5 \mathrm{~cm}$ deep) (Fig. 2). Flower buds are orange-yellow to creamy-orange in color (RHS 30B) and are pointed. When flowers open, the color changes as the petals age (dark orange with yellow base at $1 / 2$ open, light orange with bright yellow at $3 / 4$ open and yellow with white at full open). Inner petal coloration at the base are RHS 12A, in middle of the petal RHS 11B, and at the tip RHS 37C. Outer petals are RHS 12A, RHS 12C and RHS 38C, respectively. Flowers have a strong fragrance. Petal number averages 12 per flower. Petals are orbicular with a distinct point. Petal margins are smooth and slightly wavy. Anthers produce fertile pollen. Anther color varies from deep yellow to orange while filament color varies from bright yellow to orange. Style length is medium (stigma just above receptacle mouth) but below the anthers. At Morden, the receptacle is pear-shaped, green (RHS 144B), round, and generally $<2 \mathrm{~cm}$ in diameter. Sepals are 2 to $3 \mathrm{~cm}$ long, acute, green (RHS 147C, adaxilly, RHS 144B, abaxilly) and have a tomentose inner surface.

\section{Observations}

'Morden Sunrise' is a low-growing, continuous-blooming shrub rose. Mature plant size is $\approx 70 \mathrm{~cm}$ at Morden, but plants grown and overwintered in containers reached over $1.5 \mathrm{~m}$ in the second year. Plants have been under evaluation at the AAFC-Morden Research Center for over 10 years. Plants have survived in Agriculture Canada hardiness zone 3 with no protection (Ouellet and Sherk, 1967; Sherk and Buckley, 1968). Stem dieback may occur in severe winters, but regrowth generally is very good if plants are propagated on their "own roots."

Canes are very erect with few to moderate number of secondary branches. At Morden, flower production begins in early June from previous season's buds, continues on current

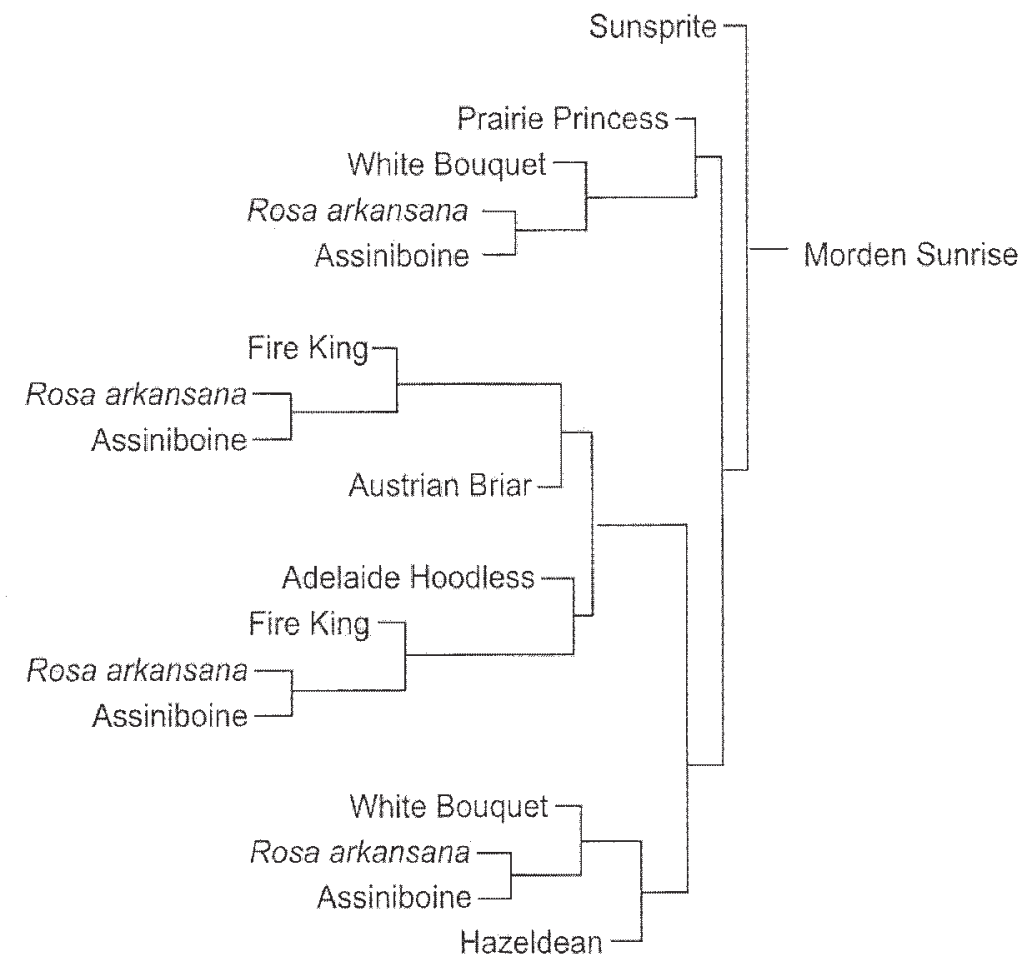

Fig. 1. Pedigree of 'Morden Sunrise' rose. 


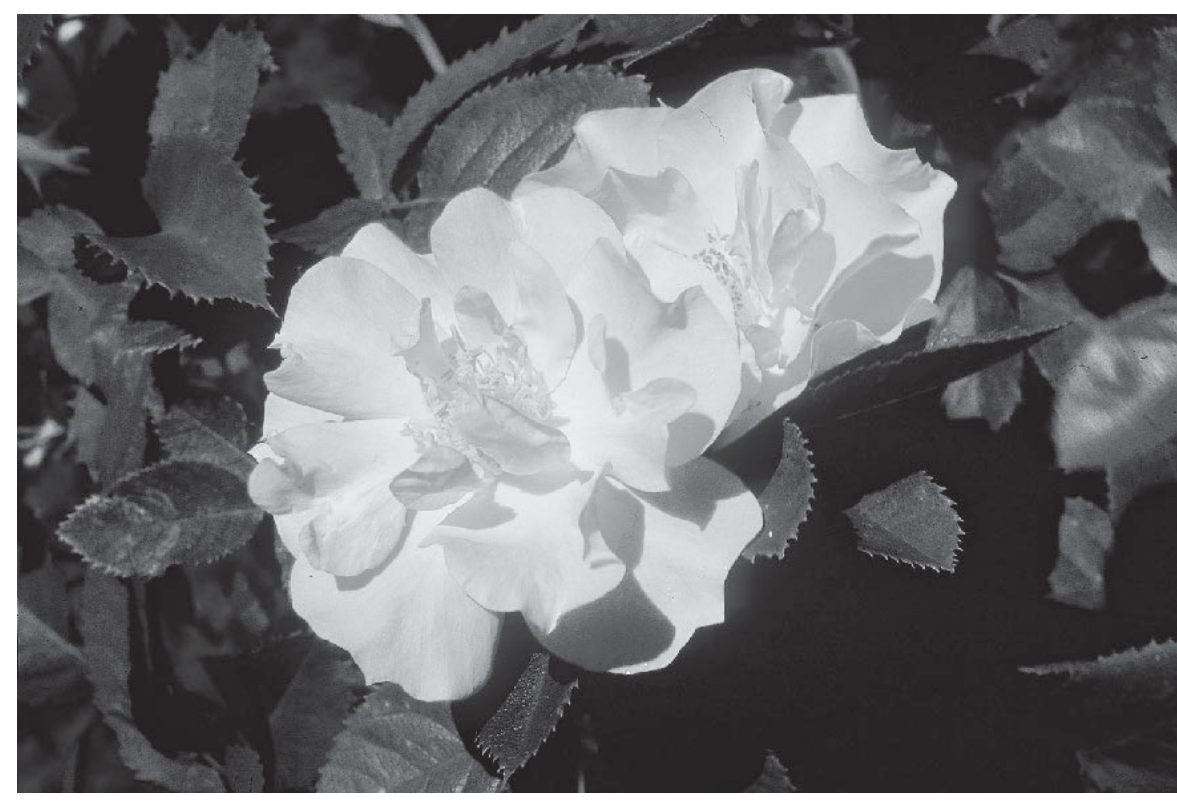

Fig. 2. 'Morden Sunrise' rose.

season growth and generally is completed by the middle of September (mean duration 15 weeks) (Table 1). 'Morden Sunrise' is one of the earliest blooming Parkland roses. The blossom coverage $(0=$ no flowers; $100=$ $100 \%$ coverage of the whole plant) compares favorably with that of other Parkland roses, other yellow flowered shrub roses at Morden, and the parents used in the cross (Table 1). Hips are formed each season, but often do not ripen fully under our conditions.

Disease screening trials indicate good resistance to local populations of blackspot (Diplocarpon rosae Wolf.), powdery mildew [Sphaerotheca pannosa (Wallr. ex Fr.) Lev.], and rust (Phragmidium sp.) (data not presented). Xue and Davidson (1998) identified to blackspot); long period of bloom; dark, shiny, green leaves; and hardiness.

\section{Propagation and Uses}

'Morden Sunrise' is propagated by softwood cuttings, as are other members of the Parkland rose cultivar group. This is important for colder regions where most budded or grafted roses often suffer winter injury to the scion portion of the plant, and the resulting growth may be from the rootstock only. Softwood cuttings of 1 to 3 nodes in length, taken during late spring through mid-summer, treated with rooting hormone (e.g., 3000$5000 \mathrm{mg} \cdot \mathrm{L}^{-1}$ indole butyric acid), and placed under intermittent mist or fog will root at high rates $(>85 \%)$. Also, plants may be propagated by tissue culture.

'Morden Sunrise' is suitable for a wide variety of landscape applications from individual plants to mass planting. The yellow flower color and good blackspot disease resistance are characteristics that should contribute to wide-scale utilization in the landscape.

the importance of partial resistance to blackspot as a key component in the future development of garden roses. Components examined included incubation period, leaf area with symptoms, number of lesions, lesion length, and sporulation capacity. Differences in cultivar/selection responses were found for all components. Both 'Morden Snowbeauty' (Davidson, 1999a) and 'Morden Sunrise' (tested as Y2) were identified as having a high level of partial resistance to black spot, which was critical in the decision to release these roses.

'Morden Sunrise' can be distinguished from other yellow-flowered shrub roses based on a number of characteristics: small stature; semidouble flowers; disease resistance (especially

\section{Availability}

'Morden Sunrise' rose is registered with the Canadian Ornamental Plant Foundation (COPF), P.O. Box 21083, North Bay, ON, P1B 7N8, Canada, and with the American Rose Society, P.O. Box 30,000, Shreveport, LA 71130-0030. Exclusive propagation and distribution rights have been awarded to: $\mathrm{COPF}$ for Canada, Bailey Nurseries, 1325 Bailey Road, Newport, MN 55055-9597 in the United States and Pan American, 5151 - 152 St. Surrey, BC, V4P 2J9, Canada in the ASEAN and EC countries. Research propagation material is available on a limited basis after signing a nonpropagation agreement.

Table 1. Mean percentage of flower cover ${ }^{\mathrm{Z}}$ and flowering duration of selected rose cultivars at the AAFC-Morden Research Station during the growing seasons of 1994-97.

\begin{tabular}{|c|c|c|c|c|c|c|c|c|c|c|c|c|c|c|c|}
\hline \multirow[b]{2}{*}{ Cultivar ${ }^{\mathrm{y}}$} & \multicolumn{15}{|c|}{ Week $^{x}$} \\
\hline & $\overline{23}$ & 24 & 25 & 26 & 27 & 28 & 29 & 30 & 31 & 32 & 33 & 34 & 35 & 36 & 37 \\
\hline Adelaide Hoodless (P) & 0.0 & 0.0 & 15.0 & 20.0 & 30.0 & 10.0 & 10.0 & 5.0 & 5.0 & 5.0 & 10.0 & 10.0 & 5.0 & 10.0 & 10.0 \\
\hline Blanc Double de Coubert (R) & 0.0 & 5.0 & 15.0 & 10.0 & 10.0 & 10.0 & 15.0 & 10.0 & 15.0 & 15.0 & 15.0 & 10.0 & 15.0 & 0.0 & 0.0 \\
\hline Henry Hudson (R) & 0.0 & 0.0 & 15.0 & 20.0 & 30.0 & 35.0 & 25.0 & 10.0 & 5.0 & 5.0 & 5.0 & 5.0 & 15.0 & 10.0 & 10.0 \\
\hline Morden Amorette (P) & 0.0 & 0.0 & 15.0 & 18.3 & 28.3 & 21.7 & 11.7 & 8.3 & 20.0 & 15.0 & 20.0 & 25.0 & 13.3 & 10.0 & 5.0 \\
\hline Morden Blush (P) & 0.0 & 6.0 & 40.0 & 30.0 & 26.0 & 20.0 & 12.0 & 16.0 & 24.0 & 24.0 & 20.0 & 16.0 & 14.0 & 4.0 & 0.0 \\
\hline Morden Snowbeauty (P) & 0.0 & 2.0 & 32.0 & 28.0 & 26.0 & 18.0 & 16.0 & 14.0 & 26.0 & 22.0 & 18.0 & 14.0 & 10.0 & 10.0 & 6.7 \\
\hline Morden Sunrise $(\mathrm{P})$ & 2.0 & 4.0 & 12.0 & 10.0 & 20.0 & 20.0 & 18.0 & 18.0 & 18.0 & 18.0 & 22.01 & 16.0 & 10.0 & 8.0 & 2.0 \\
\hline Prairie Joy $(\mathrm{P})$ & 0.0 & 0.0 & 18.3 & 30.0 & 25.0 & 16.7 & 20.0 & 21.7 & 15.0 & 11.7 & 15.0 & 11.7 & 8.3 & 5.0 & 10.0 \\
\hline Prairie Princess (B) & 0.0 & 5.0 & 5.0 & 5.0 & 15.0 & 5.0 & 5.0 & 5.0 & 5.0 & 10.0 & 10.0 & 10.0 & 10.0 & 0.0 & 0.0 \\
\hline Mean & 0.2 & 2.4 & 18.6 & 19.0 & 23.4 & 17.4 & 14.7 & 12.0 & 14.8 & 14.0 & 15.0 & 13.1 & 11.2 & 6.3 & 4.9 \\
\hline
\end{tabular}

${ }^{\mathrm{z}}$ Scale: $0=$ no flowers, $10=10 \%$ coverage of the whole plant, etc.

y $\mathrm{P}=$ Parkland roses; $\mathrm{R}=R$. rugosa shrub rose; $\mathrm{B}=$ hybrid roses developed by the late $\mathrm{G}$. Buck, Iowa State Univ.

${ }^{\mathrm{x}}$ Week $23=4$ June; week $37=16$ Sept.

\section{Literature Cited}

Cairns, T. 1993. Modern roses 10. Amer. Rose Soc., Shreveport, La.

Collicutt, L.M. 1992. Hardy-rose breeding at the Morden Research Station. HortScience 27:1070, 1147.

Davidson, C.G. 1999a. 'Morden Snowbeauty' rose. HortScience 34:366-367.

Davidson, C.G. 1999b. Breeding and development of cold hardy roses, ASHS annual meeting, St. Paul, Minn. HortScience 34:562 (Abstr. 664). (In press for HortTechnology).

Marshall, H.H. 1977. New rose series meets demand. Canada Agr. 22:24-26.

Ouellet, C.E. and L.C. Sherk. 1967. Woody ornamental plant zonation. III. Suitability map for probable winter survival of ornamental trees and shrubs. Can. J. Plant Sci. 47:3513-3518.
Royal Horticultural Society. 1986. Royal Horticultural Society Colour Chart. London.

Sherk, L.C. and A.R. Buckley. 1968. Ornamental shrubs for Canada. Canada Dept. Agr. Publ. \#1286, Research Branch, Ottawa.

Xue, A. G. and C.G. Davidson. 1998. Components of partial resistance to black spot disease (Diplocarpon rosae Wolf) in garden roses. HortScience 33:96-99. 